\title{
Internship and Private Fellowship: Why is it Difficult for Companies to Find Suitable Candidates?
}

\author{
Bogdan RUSU \\ “Gh. Asachi” Technical University of Iaşi, Romania \\ bmcrusu@tuiasi.ro
}

\begin{abstract}
This exploratory study aims to identify the factors that prevent companies to find suitable candidates for private fellowships and internships: what students believe to be the causes, how would they explain these and which stakeholders should be involved to eliminate them. Data collection based on a sample of 18 engineering students that attended a company presentation inviting applications for private fellowship and student practice. Opinions were expressed in writing prior to structured interviews and group discussions. Limitations to this study are the relatively small sample size $(n=18)$ and reliance on selfreport measures. Information related causes were perceived by the students to lead their decisions, followed by lack of self-confidence of successful application for the grant. Respondents were classified in „Doers“, „Wishers “and „Lagers“. Universities must reinvent themselves in order to provide students with better knowledge and confidence on the job market, measured through a larger number of doers, which could become role models for wishers. Such process may generate a "critical mass" or tipping point in the transformation of a significant number of "wishers and lagers". Whilst some of the students' opinions are subjective, cooperation between universities and companies must continue to improve in order to enhance learning and better prepare students for their future careers.
\end{abstract}

Keywords: student fellowship, self-confidence, qualitative research

\section{INTRODUCTION}

Economic crisis hit hard many organizations and companies. Forced to restructure and reduce their activity the firms had to lay down personnel leading to high unemployment rates, especially among youth. Even in harsh economic conditions, some companies sustained their efforts to provide students with internships, practice placements and private funded grants. The author noticed the discontent of the representatives of such a company with the reluctance of students to apply for such grants, based on a job fare event for students.

This qualitative research aims to gather data regarding student's perceptions on the causes why companies do not find suitable candidates for private fellowships and internships, how the students explain such causes and analyse the stakeholders that should be involved to 
eliminate them. Thus, the paper aims to contribute to the debate in the wider academic community on issues of preparing students to successfully enter the Romanian labour market.

\section{Context}

There are three kinds of grants provided by State Universities during term-time: "Study" of about 40 Euros/ month, "Merit" of about 55 Euro/ month and "Social" for students with financial difficulties of about 30 Euro/ month.

The company, a multinational from the steel industry, is located about $500 \mathrm{Km}$ from researcher's university and provides 650 scholarships across 17 countries distributed to over 80 Universities. Bursaries are particularised for each country.

In Romania, the bursaries consist of nearly 200 Euros/month for 12 months and targets engineering students from several Technical Universities/ Faculties.

Applicants must have good grades for the whole year, pass most of the exams and attend at least one meeting with the company providing the grant. There were no other specific requirements for the recipient "no strings attached", as expressed by the representative of the company such as compulsory practice/ summer work or employment after graduation. She provided a contact data for a student, which was the recipient of the grant for three consecutive years and declined twice a contract to work for the company after graduation. The student confirmed the information. Analysis of a copy of the contract from another grant's recipient revealed that there were no conditions stipulated for the grand beneficiary except from keeping up the hard work and continue to receive good grades.

In Romania, technical universities' students must do "student practice". Therefore, for the recipients of the grant the company would facilitate practical training (i.e. internship, part time employment or practice).

\section{LITERATURE REVIEW}

Since 2005, in United State occurred a shift from Need Based to Merit-Based grants (Doyle, 2006) to provide a better use of the money. A study of the impact of financial aid on student dropout from or the completion of higher education (Arendt, 2013) revealed that impact on dropout rates was higher for students from a lower socio-economic background. Grants lowered the number of work hours while studying. Persistence in college and college graduation likelihood of low-income students may be enhanced through financial aid that lowers economic barriers for low-income students (Alon 2011, Gentry 2014).

Scholars researched student's belief in themselves through optimism (Tschannen-Moran, Bankole, Mitchell, \& Moore Jr., 2013) as a composite measure of student trust in teachers, academic press and student identification with school related with student achievements. Work experience through student practice, employment and internships has a direct impact 
on student's acquired "soft" skills (Cord, Sykes, \& Clements, 2011) and self-confidence (Hynie, Jensen, Johnny, Wedlock, \& Phipps, 2011).

There are mixed reports of the benefits of part-time work during academic studies. Discouraged university students are reluctant to work during term-time and combine studies and work (Mihail \& Karaliopoulou, 2005). Whilst part-time work not necessarily degree related represents a source of income, some of these experience provides rich learning experiences for students (Shaw \& Ogilvie, 2010). Thus, students become aware of the recruitment process, challenges and issues that occur in real organizations, develop self-marketing, and job search skills (McCorkle, Alexander, Reardon, \& Kling, 2003).

Across industries, faculties are seeking to improve job placement rates for their graduates (Chi \& Gursoy, 2009).

\section{METHODOLOGY}

This research is an exploratory, qualitative study of the perceptions of private fellowships and internships among engineering students and the causes that prevents companies to find suitable candidates. Semi structured interviews and an "informal" focus group were used for data collection. The sample consists of 18 students, plus 5 others that were there by chance and only attended for 15 minutes. All had been exposed to the presentation of the Company's representative that complained of the lack of interest from the students for their grant program.

In order to stimulate individual answers and avoid "borrowing" other's ideas from the group, the participants were required to fill in some forms as semi-structured questionnaire prior to discussions. Thus was enhanced the expression of their own perceptions and ideas, limiting the influence of the group where they could "hide" and say that they agree with their colleagues.

Participants agreed for the discussions to be voice-recorded to enable later evaluation and to free the flux of ideas and emotions flow uninterrupted.

\section{RESULTS}

\section{Student perceptions regarding the „Causes why” the company do not find suitable candidates}

Analysis of the written forms and interviews revealed 6 categories of causes perceived by the students (Information; Experience (professional); Lack of self-confidence; Faculty; Students ; Company), depicted in table 1.

Table 1. Factors and their influence for each category of causes

\begin{tabular}{l|l|l} 
CAUSE & FACTORS & EXPLANATION
\end{tabular}




\begin{tabular}{|c|c|c|}
\hline \multirow[t]{3}{*}{$\begin{array}{l}\text { 1.INFORMATION } \\
\text { "No strings } \\
\text { attached" }\end{array}$} & $\begin{array}{l}\text { LACK OF / } \\
\text { INSUFFICIENT } \\
\text { planning and } \\
\text { preparation of the } \\
\text { promotion campaign }\end{array}$ & $\begin{array}{l}\text { - Students are not informed or it / } \\
\text { Arrives too late to the students } \\
\text { - It is INCOMPLETE } \\
\text { - Therefore Students DO NOT TRY } \\
\text { AT ALL }\end{array}$ \\
\hline & $\begin{array}{l}\text { GRANT } \\
\text { ALLOCATION } \\
\text { CRITERIA }\end{array}$ & $\begin{array}{l}\text { - There are NOT presented the } \\
\text { CONDITIONS or } \\
\text { - Those conditions are NOT CLEAR } \\
\text { for Grant ALLOCATION } \\
\text { - Criteria are perceived or presented } \\
\text { with ERRORS }\end{array}$ \\
\hline & $\begin{array}{l}\text { RARITY of such } \\
\text { PRIVATE GRANTS }\end{array}$ & $\begin{array}{l}\text { - Not promoted on a WEB SITE } \\
\text { - No Web site dedicated/ specialized } \\
\text { on private fellowship/ internship }\end{array}$ \\
\hline 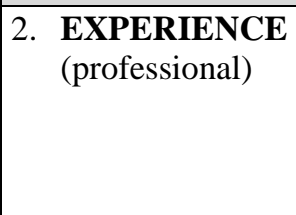 & $\begin{array}{l}\text { LACK OF or } \\
\text { INCOMPLETE } \\
\text { NOT RELEVANT } \\
\text { (as perceived by the } \\
\text { student) }\end{array}$ & $\begin{array}{l}\text { FEAR TO APPLY for both } \\
\text { private fellowship and internship }\end{array}$ \\
\hline $\begin{array}{l}\text { 3. LACK of } \\
\text { SELF- } \\
\text { CONFIDENCE }\end{array}$ & $\begin{array}{l}\text { Personal perception } \\
\text { of LACK OF } \\
\text { CREDIBILITY }\end{array}$ & $\begin{array}{l}\text { WHY do they GIVE THE GRANT } \\
\text { with NO STRINGS ATTACHED } \\
\text { "IT MUST BE } \boldsymbol{A} \text { CATCH" }\end{array}$ \\
\hline 4. FACULTY & $\begin{array}{l}\text { Academic staff } \\
\text { should put on less } \\
\text { theory and made it } \\
\text { better applied } \\
\text { More PRACTICAL } \\
\text { WORK }\end{array}$ & $\begin{array}{l}\text { Courses and seminars to be more } \\
\text { practical oriented } \\
\text { To do practice in a company for the } \\
\text { equivalent of } 1 \text { day a week }\end{array}$ \\
\hline \multirow[t]{3}{*}{ 5. STUDENTS } & $\begin{array}{l}\text { GRADES too small } \\
\text { Distance too great } \\
\text { between Co. location } \\
\text { and student residence }\end{array}$ & $\begin{array}{l}\text { Do not learn enough } \\
\text { "Laziness"- just a reason to justify } \\
\text { why did not apply. What about } \\
\text { holidays on the sea-side. }\end{array}$ \\
\hline & Lack of interest & $\begin{array}{l}\text { Social life in the campus } \\
\text { Large group of students that are not } \\
\text { interested } \\
\text { Lack of belief that would pursue a } \\
\text { career in their field of study }\end{array}$ \\
\hline & $\begin{array}{l}\text { Incompatibility (as } \\
\text { perceived by the } \\
\text { student) }\end{array}$ & $\begin{array}{l}\text { For the job after graduation in their } \\
\text { field of study }\end{array}$ \\
\hline
\end{tabular}




\begin{tabular}{|c|c|c|}
\hline & $\begin{array}{l}\text { Do not REALLY } \\
\text { want to high grades } \\
\text { in Faculty }\end{array}$ & $\begin{array}{l}\text { Just want to go by using the } \\
\text { "minimum resistance" and got the } \\
\text { Degree }\end{array}$ \\
\hline & $\begin{array}{l}\text { Do not wish to } \\
\text { assume } \\
\text { RESPONSIBILITY } \\
\text { (be RESPONSIBLE) }\end{array}$ & $\begin{array}{l}\text { Did not discuss this issue, but I } \\
\text { presume the influence of the } \\
\text { SUPPORT (or LACK of IT) received } \\
\text { from own FAMILY and personal } \\
\text { VALUES }\end{array}$ \\
\hline & $\begin{array}{l}\text { Would like to BUT } \\
\text { CANNOT learn } \\
\text { enough } \\
\text { Doing work for } \\
\text { charity or NGOs }\end{array}$ & $\begin{array}{l}\text { Does not have good grades because } \\
\text { have to work to support themselves } \\
\text { May believe that would get a job in a } \\
\text { different specialty after graduation }\end{array}$ \\
\hline & $\begin{array}{l}\text { Do not know a } \\
\text { foreign language }\end{array}$ & $\begin{array}{l}\text { Great barrier if the company requires } \\
\text { them to (and they have to use it) }\end{array}$ \\
\hline & $\begin{array}{l}\text { See their future in } \\
\text { other countries }\end{array}$ & $\begin{array}{l}\text { Not explored and could not explain } \\
\text { this observation }\end{array}$ \\
\hline 6. COMPANY' & TO BE INVOLVED & In and with the Faculty \\
\hline
\end{tabular}

\section{Students' perceptions regarding stakeholders that should be involved to eliminate causes}

De difficulties faced by the companies in finding suitable candidates are generated by a complex interaction of factors. A sustainable solution requires a new set of rules and interactions among the four key stakeholders as perceived by the students from the sample:

- COMPANY (and the person responsible for this issue) and

- UNIVERSITY (Top Management and Academic Staff).

- $\quad$ STUDENTS (as perceived that have to play a role)

- FAMILY(not really referred to and therefore not discussed and analysed)

Table 2. Finding better candidates: stakeholders that should be involved

\begin{tabular}{|c|c|c|}
\hline STAKEHOLDER & FACTORS & EXPLANATION \\
\hline $\begin{array}{l}\text { 1. COMPANY } \\
\text { (The person } \\
\text { assigned to be } \\
\text { responsible for } \\
\text { the project }\end{array}$ & $\begin{array}{l}\text { Explains the } \\
\text { situation }\end{array}$ & $\begin{array}{l}\text { - Explicit presentation of the working } \\
\text { conditions and the procedures/ } \\
\text { process to gain the fellowship } \\
\text { - HAS the Authority and responsibility } \\
\text { - Knows the situation and has faith } \\
\text { - } \text { Convince you to apply }\end{array}$ \\
\hline $\begin{array}{l}\text { and } \\
\text { The company's } \\
\text { top }\end{array}$ & $\begin{array}{l}\text { Provides Support, } \\
\text { resources and } \\
\text { celebrates results as } \\
\text { well as }\end{array}$ & $\begin{array}{l}\text { - Active promotions of the private } \\
\text { fellowships/ Internships and Practice } \\
\text { within the company } \\
\text { - Ensures appropriate level of }\end{array}$ \\
\hline
\end{tabular}




\begin{tabular}{|c|c|c|}
\hline \multirow[t]{2}{*}{ management) } & $\begin{array}{l}\text { acknowledges the } \\
\text { partnership with the } \\
\text { University }\end{array}$ & 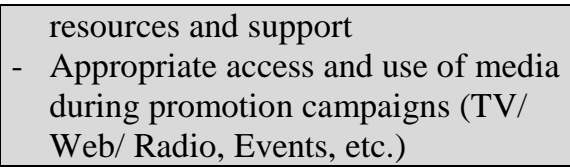 \\
\hline & $\begin{array}{l}\text { Bring in Proofs that } \\
\text { program works } \\
\text { (such as students } \\
\text { that already have } \\
\text { the grant) }\end{array}$ & $\begin{array}{l}\text { - Brings credibility to the Fellowship } \\
\text { and the way it is allocated } \\
\text { - Better Understanding of the way the } \\
\text { system works } \\
\text { - Positive Examples for the students } \\
\text { - } \text { Credibility }\end{array}$ \\
\hline 2. UNIVERSITY & $\begin{array}{l}\text { Top Management } \\
\text { Rector/ Deans }\end{array}$ & $\begin{array}{l}\text { - } \text { Students to be well prepared and "In } \\
\text { Great Demand from Companies" } \\
\text { - } \text { Vision, Support, Resources, Results } \\
\text { - } \\
\text { Acknowledges and Celebrate } \\
\text { achievements } \\
\text { - } \text { Promote the Private Fellowships and } \\
\text { Internships and support open } \\
\text { competition } \\
\text { - Important role in Influencing and } \\
\text { Motivating Students } \\
\text { - } \text { Coaching and Mentoring }\end{array}$ \\
\hline 3. STUDENTS & $\begin{array}{l}\text { OWN } \\
\text { RESPONSIBILITY } \\
\text { was barely } \\
\text { mentioned at this } \\
\text { stage }\end{array}$ & $\begin{array}{l}\text { - Required support and encouragement } \\
\text { from academic staff to improve } \\
\text { learning and receive the grant } \\
\text { - } \text { Better use of theory in practice } \\
\text { - Did not assume responsibility for not } \\
\text { applying; ALL motives are "outside } \\
\text { of their control" } \\
\text { o somebody else (...) should help } \\
\text { and } \\
\text { O Should lower their criteria }\end{array}$ \\
\hline 4. FAMILY & $\begin{array}{l}\text { Only one } \\
\text { occurrence }\end{array}$ & $\begin{array}{ll}\text { - } & \text { No reference or explanation } \\
& \text { regarding involvement of parents }\end{array}$ \\
\hline
\end{tabular}

\section{DISCUSSION}

Information related causes (including lack of it) are perceived by the student to have the greatest impact on the scarcity of suitable candidates reported by the company. Promotion activity should provide clear, concise and verifiable (trustworthy) information, including appropriate means that would make applicants believe that "no strings are attached" to such offer.

Whilst during job fare event there were former grand recipients on the company's stand that could provide details regarding the grand and confirm that the contract did not include 
any conditions for the recipient, none of the 18 students from the sample asked for further information or made an application.

Second important factor that deters students to apply relates to Lack of SELF CONFIDENCE. It roots both in limited personal experience, as he/she knows that did not work and believes that has no credibility (proved by grades, knowledge of a foreign language, knowledge of theory and practical application). Such negative self-perception fuels fears of rejection and pain of seeing reality which determines the student not to try. The researcher was told by some students that whilst being invited to interviews they decided not to go because they may not get the job, or leave the comfort of his/her present emotional life.

For most of the students from the sample, there is no self-reflection and career planning and therefore very limited desire to actively work toward finding an internship position or a private fellowship. Few respondents reported self-awareness and acknowledgment of the importance of practical experience (for internship) and good grades (no work during termtime based on private fellowship). However, there was no evidence of application forms towards companies that could enable such experiences.

Further research should include qualitative and quantitative study of the students' life goals, aspirations and preparation for employment.

Data analysis revealed three categories of students, based on their specific behaviour: DOERS, WISHERS and LAGERS

1. DOERS are very rare, they have well established aims and objectives regarding their career and had already engaged in actions in order to achieve them and have excellent grades. There are some doers that are engaged, know where they are going but do not have good grades because they work or value more their „practice” for what they will do after graduation.

2. WISHERS constitute a small group, larger than doers. They ask themselves some problems (in terms of aims and objectives) but there are few concrete actions to reflect on their learning and assuming responsibility for their life.

3. LAGERS does not have aims, objectives and do not acknowledge the importance and impact of their actions. They seek motives for their actions that are outside of their control and therefore justify their lifestyle and achievements.

Whilst not proven, the author presumes that there were at least a critical event in DOER's life that forced them to assume responsibility, or they had a harsh life. Such opinion bases on some informal private discussions with students that acknowledged that they had no parents or single parent that had to support 5 brothers. They needed the university bursary and therefore had excellent performance in the University.

Not all single parent students focused on learning. Some other student reported that her mother and sister over protected her by sending money during a time when she was also receiving government help for her deceased father. 
Subsequent interviews with company's representative and academic staff with managerial positions from the university confirmed that in each year there were some recipients of this private grant, without clearly identifying the persons, the number of bursaries awarded or a brief video presentation of the recipients stating their specific achievements due to receiving this grant.

\section{CONCLUSIONS AND RECOMMENDATIONS}

This paper aims to contribute to debates in the wider academic community on the issue of preparing young, well-educated people to be better prepared to enter the Romanian labour market.

Whilst may be an isolated case where students did not enrol for private fellowship, the qualitative research revealed strong perception of students that they were "not provided" with enough information, encouragement, support in order to apply. Many students from the sample also perceived themselves as not having enough theoretical and practical knowledge, which generated lack of self-esteem leading to abstinence in applying for the grant. Informal discussions with some $3^{\text {rd }}$ and $4^{\text {th }}$ year students revealed that many either did not apply or received no feedback to their application from the companies.

The solution requires joint efforts of University and Private enterprises (Gault, Leach, \& Duey, 2010). All faculties already had taken significant steps to improve the quality and quantity of applications through organizing student practice in companies, improved communication through web site and exhibiting the calls for applications from interested firms. They should continue to adapt and improve the curriculum in order to meet the continuously changing industry needs (Chi \& Gursoy, 2009). Such actions would gradually improve students' self-confidence and determine a larger number to apply and be accepted by the companies.

Some students were reluctant to involve their family and/or stated that even if the family would be involved, they would not change present attitudes and behaviours. There were no references to spiritual life that may also play a role in influencing decisions.

\section{Limitations of the study}

The main limitation is due to a relatively small sample size $(n=18)$ and reliance on selfreport measures by respondents.

Whilst there may be other companies to offer grants and internships, the paper only focuses on this firm. The study should be extended to include cohorts of students attending other company's presentations from both engineering and non-engineering students and universities, and compare data with company's information on the number of applicants and successful candidates. 


\section{REFERENCES}

Alon, S. (2011). Who Benefits Most from Financial Aid? The Heterogeneous Effect of Need-Based Grants on Students' College Persistencence. SOCIAL SCIENCE QUARTERLY, 92(3), 807-829.

Arendt, J. N. (2013). The effect of public financial aid on dropout from and completion of university education: evidence from a student grant reform. Empirical Economics(44), $1545-1562$.

Chi, C. G., \& Gursoy, D. (2009). How to help your graduates secure better jobs? An industry perspective. International Journal of Contemporary Hospitality Management, 21(3), 308-322.

Cord, B., Sykes, C., \& Clements, M. (2011). Who cares wins: owning the learning transition. Development and Learning in Organizations, 25(4), 20-22.

Doyle, W. R. (2006). Adoption of Merit-Based Student Grant Programs: An Event History Analysis. Educational Evaluation and Policy Analysis, 28(3), 259-285.

Gault, J., Leach, E., \& Duey, M. (2010). Effects of business internships on job marketability: the employers' perspective. Education + Training, 52(1), 76 - 88.

Gentry, R. (2014). Sustaining college students' persistence and achievement through exemplary instructional strategies. Research in Higher Education Journal, 24(August).

Hynie, M., Jensen, K., Johnny, M., Wedlock, J., \& Phipps, D. (2011). Student internships bridge research to real world problems. Education + Training, 53(2/3), 237248.

McCorkle, D. E., Alexander, J. F., Reardon, J., \& Kling, N. D. (2003). Developing Self-Marketing Skills: Are Marketing Students Prepared for the Job Search? Journal of Marketing Education, 25, 196-207.

Mihail, D. M., \& Karaliopoulou, K. (2005). Greek university students: a discouraged workforce. Education + Training, 47(1), 31-39.

Shaw, S., \& Ogilvie, C. (2010). Making a virtue out of a necessity: part time work as a site for undergraduate work-based learning. Journal of European Industrial Training, 34(8/9), 805-821.

Tschannen-Moran, M., Bankole, R. A., Mitchell, R. M., \& Moore Jr., D. M. (2013). Student Academic Optimism: A Confirmatory Factor Analysis. Journal of Educational Administration, 51(2), 150-175. 